Conference Paper

\title{
Training and Assistance Model: Designing and Applying Blended Learning for Teachers of SMP Muhammadiyah XIV Pondok Pesantren Karangasem Lamongan
}

\author{
Ika Korika Swasti ${ }^{*}$, Aphief Tri Artanto² \\ ${ }^{1}$ Faculty of Economics and Business, Universitas Pembangunan Nasional "Veteran" Jawa Timur, Indonesia \\ ${ }^{2}$ Faculty of Architecture and Design, Universitas Pembangunan Nasional "Veteran" Jawa Timur, Indonesia
}

${ }^{*}$ Corresponding author

E-mail:

ikaks.ma@upnjatim.ac.id

\begin{abstract}
The purpose of this training and mentoring is to transfer the development of learning media to strengthen e-learning based on information and communication technology (ICT). Solving the needs of partners is done with strategies, namely: empowering teachers to create ICT-based learning media, lectures on blended learning, and platforms. e-learning media. Practice making blended learning teaching media. The approach used is Participatory Rural Appraisal by involving UPNV JT community service implementers as facilitators or resource persons. The training participants are five teachers who are assisted and trained as cadres, then the knowledge is shared with other teachers to be implemented in learning. Assistance after training is still carried out online. After the training and mentoring were carried out, the teachers of SMP Muhammadiyah 14 Pondok Pesantren Karangasem Lamongan who were trained to design and implement blended learning: (a) have increased their knowledge regarding the understanding and implementation of blended learning; (b) has been able to convert PPT into visual learning media using Movavi software; (c) can use the equipment owned (laptop; smartphone), and perform editing using Movavi. The learning media used by the teacher can motivate students to learn repeatedly and is not limited by time and space.
\end{abstract}

Keywords: mentoring, training, design, implementation, blended learning

\section{Introduction}

The Covid-19 pandemic in Indonesia has changed the education system from face-to-face to online. Adaptation to this change is felt by all components, starting from teachers, students, administrative staff, and other components. The current condition is faced with the challenges of using information and communication technology (ICT) that is integrated with the education system, especially during the Covid-19 pandemic which demands online learning. The study from the home policy set by the Minister of Education during the Covid-19 Pandemic demands schools to innovate. The use of ICT is of course designed systemically and systematically so that this technology can add value to the learning process. The integration of ICT in learning is the emergence of innovative learning products such as online learning, e-learning that covers blended learning. Technology has changed the way we live our lives, also in education. E-Learning as a way of communicating and learning in a virtual environment that is similar to real-world interactions. Blended learning accustoms students to interact with each other, discuss, exchange opinions or ideas about certain problems (Astuti \& Novita, 2019). With continuous improvement in technology, e-learning has become less static and more socially interactive (FitzPatrick, 2012). Electronic learning (e-learning) is a means of support so that individuals, groups, and organizations can get a better learning experience.

\section{How to cite:}

Swasti, I. K., \& Artanto, A. T. (2021). Training and assistance model: Designing and applying blended learning for teachers of SMP Muhammadiyah XIV Pondok Pesantren Karangasem Lamongan. $5^{\text {th }}$ International Seminar of Research Month 2020. NST Proceedings. pages 304-311. doi: 10.11594/ nstp.2021.0947 
Blended learning is a learning strategy that aims to achieve goals by combining classbased/face-to-face learning with information and technology-based learning conducted online. The term blended learning is used to describe a solution that combines several different delivery methods, such as collaboration software, web-based courses, EPSS, and knowledge management practices (Graham, 2006). Blended learning is also used to describe learning that combines various event-based activities, including face-to-face classrooms, direct e-learning, and independent learning. According to Graham (2013) explains that starting from this view, blended learning becomes a new learning strategy that provides many benefits for students, as well as a form of support for information and communication technology towards new learning modes. In higher education learning, blended learning usually consists of face-to-face class meetings once per week, online learning to complete group projects and other class assignments (Molenda, 2008). The addition of appropriate learning innovations will result in the independence and confidence of students who have tried to explore and explore not only teachers.

E-Learning-based Blended Learning during the Covid-19 Pandemic on Teachers of SMP Muhammadiyah XIV Pondok Pesantren Karangasem Lamongan is certainly more optimal with the use of information technology which has a standard internet platform that can be a solution to these problems. The advantage of using the internet itself is that it allows everything to be connected and the character of the internet is cheap, simple, and open so that the internet can be used by anyone (everyone), anywhere, anytime (every time), and free to use (available to every) one). E-learning as a new learning model in education provides a big role and function for the world of education, which has so far been burdened with the many shortcomings and weaknesses of conventional education (education in general), including the limitations of space and time in the conventional education process. Thus, the use of ICT in the blended learning process is expected to run effectively and provide benefits in the current era of digitalization.

Various community services have implemented information and communication technology (ICT). In the business world, it is known as e-business or e-commerce, in the world of government it is known as e-government and for the world of education, it is known as e-learning. The Ministry of National Education as an organization that functions to manage education in Indonesia welcomes the development of ICT by incorporating a curriculum with the nuances of introducing information and communication technology, especially at the secondary education level. This response shows that the Ministry of National Education is paying attention to developments in the world of information and communication technology which are currently experiencing rapid progress. This policy aims to provide students with the ability to know, understand, and interact with the world of information and communication technology, so that later when they graduate they are not completely blind to the world of information and communication technology in society.

\section{Material and Methods Situation Analysis}

The demands that must be carried out by teachers and schools of SMP Muhammadiyah XIV Pondok Pesantren Karangasem Lamongan in implementing the learning process that utilizes information and communication technology face various obstacles, including limited physical resources, human resources, and learning resources based on computer and telecommunications technology. Therefore, during the Covid-19 pandemic, the PIHAT team from UPN Veteran East Java is trying to conduct E-Learning-based Blended Learning Assistance and Training to help solve learning problems faced in this school so that learning continues to run effectively.

In connection with the implementation of information and communication technology-based learning, especially the use of e-learning as an alternative media for learning, schools need to carry out needs analysis, prepare the necessary needs, design learning models and develop them (Saba, 2011). The successful application of the E-learning education system as one of the main approaches in managing knowledge and educational needs will not be achieved without identifying 
different skill, technical and cultural challenges. Blended learning needs habituation so that students and teachers are accustomed to using and developing learning materials through e-learning.

\section{Partner Problem Solving Solutions}

Based on the identification of partner problems that have been identified and as an effort to improve the quality of learning in realizing the concept of computer and information technologybased schools, the following solutions are proposed:

Table 1. Solutions to specific problems faced by partners

\begin{tabular}{lll}
\hline No & Partner Problem & Problem Solving Method \\
\hline 1. $\begin{array}{l}\text { The problem of realizing technology- } \\
\text { based blended learning information } \\
\text { and computers }\end{array}$ & $\begin{array}{l}\text { Technology transfer of ICT-based learning } \\
\text { media for e-development learning }\end{array}$ \\
$\begin{array}{l}\text { Difficulties in Finding a Facilitator to } \\
\text { Realize Learning }\end{array}$ & $\begin{array}{l}\text { The training of making learning media based on } \\
\text { MOVAVI ICT as a learning medium for Theory, } \\
\text { assignment, instructions for extracting the } \\
\text { material. }\end{array}$ \\
3. Difficulty Finding e-learning-based \\
$\begin{array}{l}\text { blended learning assistance for } \\
\text { teachers }\end{array}$
\end{tabular}$\quad$\begin{tabular}{l}
$\begin{array}{l}\text { Assistance for teachers Operational assistance } \\
\text { for the use of ICT to realize e-learning-based } \\
\text { blended learning: Theory, assignment, } \\
\text { instructions for extracting the material. }\end{array}$ \\
\hline
\end{tabular}

\section{Blended learning learning model}

According to Graham (2006), there are two types of blended learning environments, namely: (1) traditional face-to-face learning environments; and (2) a distributed learning environment that has begun to evolve along with new technologies that allow the expansion of distributed communication and interaction. Blended learning is a hybrid learning concept that integrates traditional classroom sessions and elements of e-learning in an attempt to combine the benefits of both forms of learning. Combining two forms of learning, namely face-to-face learning and online learning, making it possible for learning not only to occur in class but also outside the classroom (Yaman \& Graf, 2010; Collis \& Moonen, 2002). Blended learning is a learning program that uses more than one method to provide information to students. Learning that combines face-to-face systems with technological instruction as mediation (Shroff \& Vogel, 2010; So \& Bonk, 2010). So blended learning is a learning concept that combines traditional learning and the use of technology that allows learning not only to be carried out in class but can occur without the limitations of space and time. Students can study at any time and can repeat the same material until they get an understanding, or learn new material through e-learning media. The blended learning model continues to change from time to time, as in the following figure. 


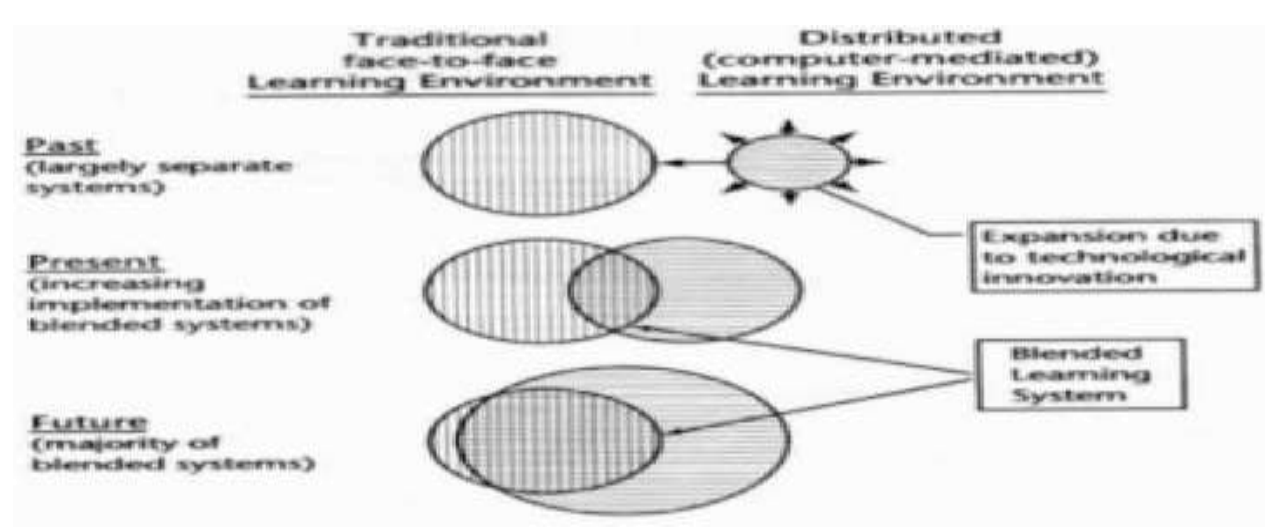

Figure 1. The blended learning models

An online learning management system (LMS) provides an interactive environment in communication between students and teachers (Yuen, 2011). In the past, the two learning environments in the blended learning model were still used separately because they used different combinations of media and methods and were used for the needs of different learners (Zuvic-Butorac et al., 2011). This type of face to face learning occurs in a teacher-directed environment with person-to-person interactions in live synchronous (time-dependent direct learning) and high-fidelity environments. Whereas the distance learning system emphasizes self-paced learning and learning with material interactions that occur in an asynchronous (independent of time) and low-fidelity environment (text only). Nowadays, the term blended learning model is already at the stage of combining the two environments above, no longer separate. This means that there are times when learning uses the same method, media, and audience, namely by using web-based learning. This is different from the term blended learning model in the future because in the future the blended system will dominate learning more than blended learning now. This means that face to face learning will be increasingly abandoned. The existing traditional learning system will sink further with the culture of a learning environment that is mediated by computer and internet technology.

Basically, there are three basic stages in the blended learning model which refers to ICT-based learning, as proposed), namely: (1) seeking of information, (2) acquisition of information, and (3) synthesizing of knowledge. The stages of seeking information, including searching for information from various sources of information available in ICT, choosing critically among sources of information providers based on the content of relevant, content of validity/reliability, and academic clarity. The instructor acts as an expert who can provide input and advice to limit learners from the pile of potential information in ICT.

\section{E-learning learning}

Implementing web-based learning can be seen as a complex process that is not just carrying out the steps in instructional design models. One of the most important prerequisites for successful e-Learning implementation is the need for careful consideration of the underlying pedagogy, or how learning takes place online (Govindasamy, 2001). Pedagogy in practice is often the most neglected aspect in any attempt to implement e-Learning.

Three main learning theories are used as the basis for web-based learning, namely: behaviorism, cognitivism, and constructivism. According to Baharuddin and Wahyuni (2015), these theories are used as a framework in carrying out the learning process that is not only interesting but also able to provide space for students to be creative and actively involved throughout the learning process without feeling bored, bored, let alone bored. 
a. Behaviorism sees learning as an observable change in behavior caused by an external stimulus. They see the mind as a "black box", the response to a stimulus can be observed quantitatively, ignoring the influence of thought processes that occur in the mind.

b. Cognitivism sees learning as an internal process that involves memory, motivation, reflection, thinking, and meta-cognition. Because of this school, the human mind manipulates symbols just as computers manipulate data. Therefore, learners are considered as information processors. Cognitive psychology includes the learning process of information processing, where information is received in various senses, is transferred to short-term and long-term memory. Information undergoes a flow of transformation in the human mind until it is permanently stored in long-term memory in packets of knowledge.

c. Constructivism sees students building their knowledge from their own learning experiences. Learning can be seen as an active process, and knowledge cannot be received from outside or others. Students should be allowed to build knowledge rather than be given knowledge through teaching.

\section{Methods of approach and problem solving}

Community empowerment is a process to help increase community capacity to improve their quality of life according to community needs (Green \& Haines, 2015). This activity will continue dynamically so that the community can solve the problems faced and can make decisions freely and independently. For this reason, the UPNV JT community service implementation team offers a Participatory Rural Appraisal method which is carried out by involving more "people from partners" consisting of all stakeholders facilitated by executors who function more as resource persons or facilitators in technology transfer activities for e-learning development as learning Media.

The method of approach and problem solving as illustrated in the following pattern of training and mentoring activities.

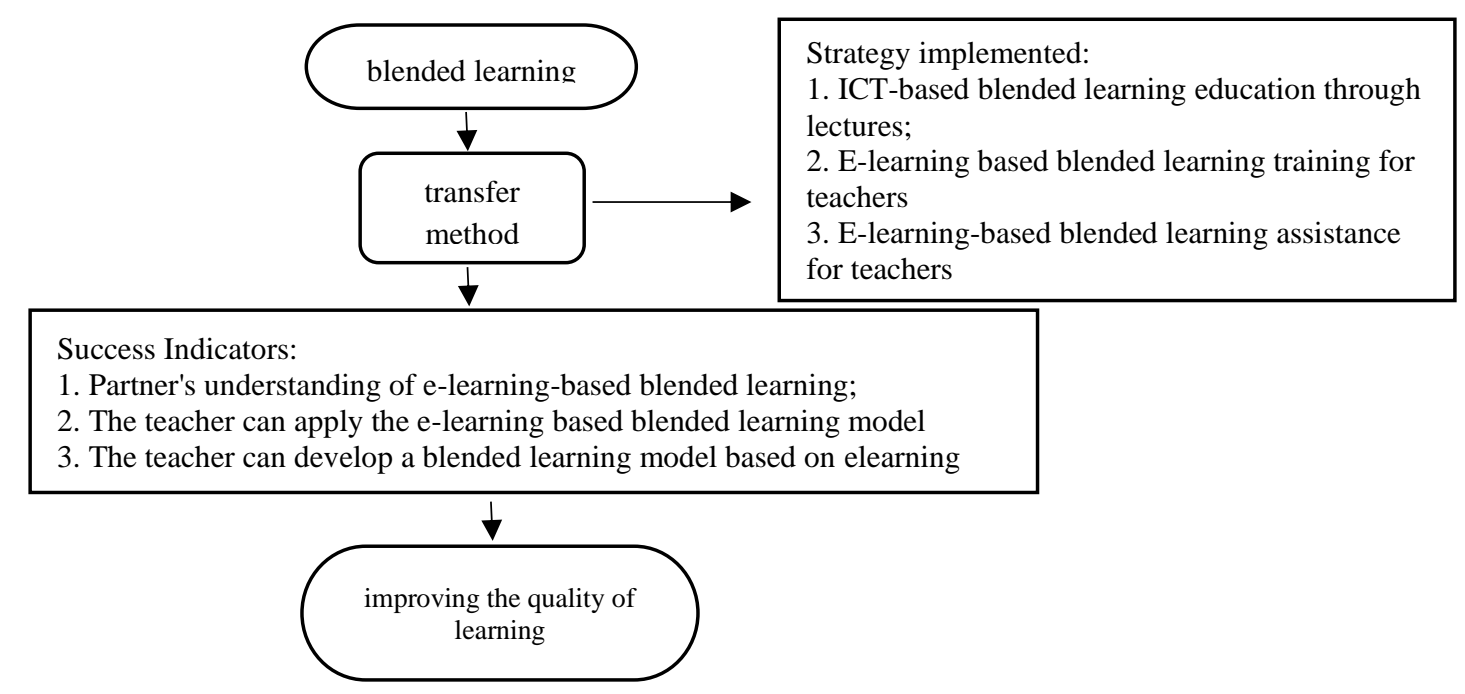

Figure 2. Training and mentoring model

The solutions offered in solving design problems and implementing blended learning are carried out by transferring methods with strategies of lectures, training, and mentoring. It is hoped that the training and mentoring provided to the five teachers who are cadres can gain understanding, apply and develop an e-learning-based blended learning model. Then transfer it to other teachers. With the ability to design and apply blended learning in learning, it is hoped that it can improve the quality of learning. 


\section{Result and Discussion Implementation of activities}

The activity begins with conducting a field survey for the work plan formulation stage. The results of the survey were used to identify problems that exist in SMP Muhammadiyah XIV, Pondok Pesantren Karangasem Lamongan. These problems then sought solutions and resulted in an agreement (the result of discussions with the Principal), namely training and assistance in designing and implementing e-learning-based blended learning for teachers. Due to conditions that made it impossible to meet directly with all the teachers, five teachers who were considered competent as cadres were chosen to be trained and assisted. This training and mentoring are carried out by providing theory and practice. Before the training began, the tutor team asked several questions to determine the level of the teachers' ability in making learning media for the development of blended learning.
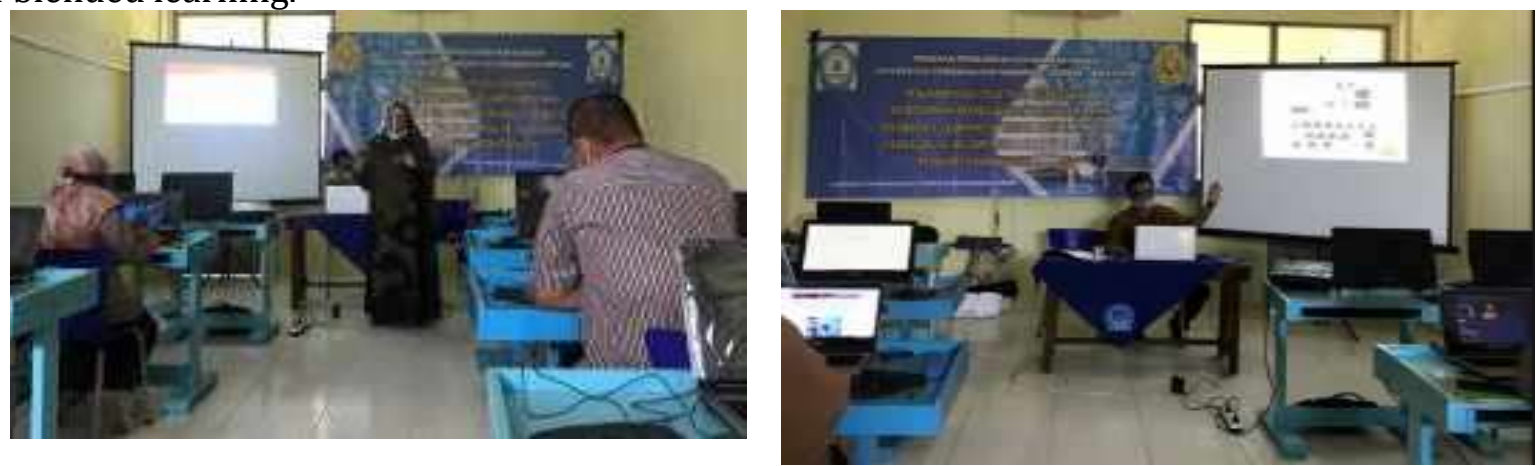

Figure 3. Delivery of blended learning materials and various e-learning platforms

The provision of material on blended learning and various e-learning platforms is carried out with lectures to introduce and equalize perceptions about blended learning. Furthermore, the tutors assist the teachers to practice the theories that have been given.
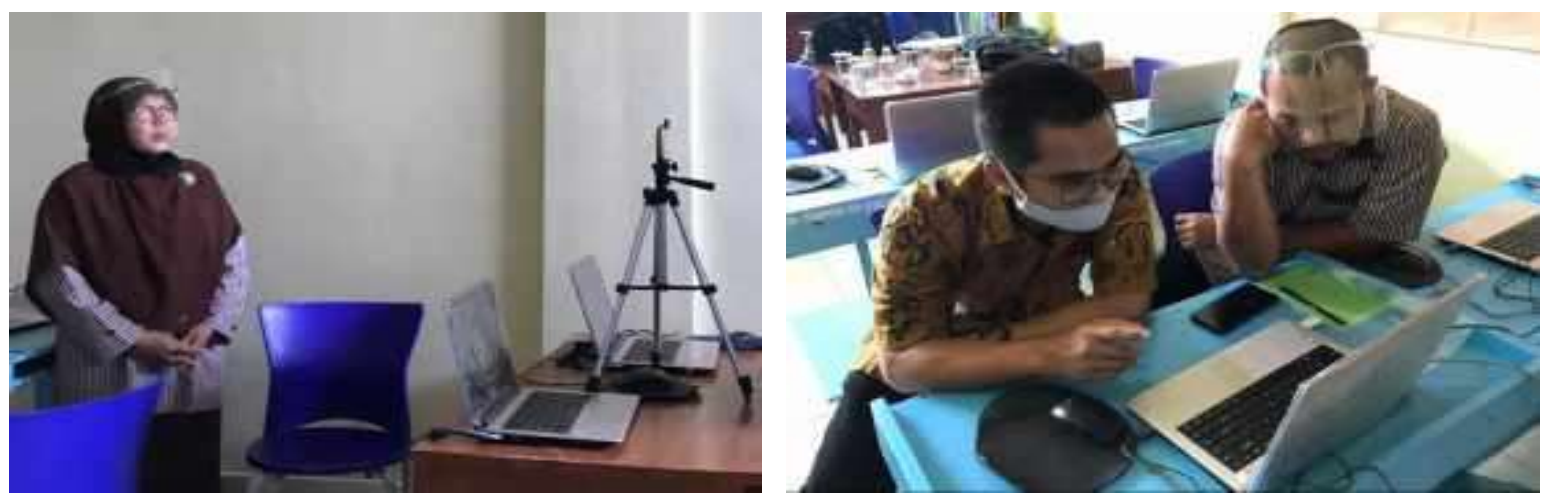

Figure 4. Planning and manufacturing practice of E-learning media

Training and practice of making learning media, how to design and implement them using electronic media in learning. Planning practices by selecting materials, creating storyboards, taking film pictures, editing, and rendering films. This training target is achieved when the teacher can produce a blended learning design using electronic media. The training does not stop here but will be assisted as long as the teacher still needs it through online means (not face to face). Further assistance is carried out online through the Whatsapp Group, aiming to communicate if there are problems in the development of learning media, you can ask directly the UPNV JT community ser- 
vice implementation team. This group is planned to be active until the end of the community service period in FY 2020. This may continue until the teachers who are trained and mentored can create ICT-based learning media. Until finally the teacher cadres can implement what they have learned and help other teachers to do blended learning with electronic media for their learning.

\section{Activity results}

The result of the activity was that the teachers were able to create e-learning based learning media using the Movavi software. The outputs obtained from this community service activity include teachers of SMP Muhammadiyah XIV Pondok Pesantren Karangasem Lamongan:

a. know blended learning methods that can be carried out amid the Covid-19 Pandemic.

b. able to make planning, production, and post-production of e-learning-based learning media with Movavi software.

While the outcome of this community service activity is expected by the teachers of SMP Muhammadiyah XIV Pondok Pesantren Karangasem Lamongan:

a. able to develop blended learning methods that are run in the middle of the Covid-19 Pandemic by combining face-to-face online learning, making learning media to strengthen elearning, student independent assignments so that learning outcomes are achieved and students can be more independent in seeking and developing knowledge.

b. able to make ICT-based learning media so that distribution becomes more attractive and able to improve learning outcomes for each subject.

The synergy of the UPNV JT campus and the SMP Muhammadiyah XIV Pondok Pesantren Karangasem Lamongan in carrying out community service programs can answer the problem of developing blended learning in the midst of the Covid-pandemic 19. Through community service activities, the teachers of SMP Muhammadiyah XIV get additional knowledge and skills (empowerment) in the development of e-learning-based learning media and blended learning knowledge.

\section{Conclusion}

After the implementation of the PIHAT program of UPN Veteran East Java, it can be concluded that the teachers of SMP Muhammadiyah XIV Pondok Pesantren Karangasem Lamongan who were trained to design and implement blended learning have increased their knowledge regarding the understanding and implementation of blended learning. The learning system in Blended Learning is flexible because students can organize learning according to time, place, path, and speed. So that students can optimize their knowledge. Also, it allows for asynchronous and synchronous learning interactions.

The blended learning design made by the teachers will allow students to learn at the same time. In contrast, contemporary design learning is usually done within a certain time in carrying out learning such as doing quizzes, reviews about chat services, and so on. Training and mentoring for teachers have been able to develop the ability to make learning media starting from planning by selecting important subject matter delivered, making storyboards, taking pictures (films), carrying out film editing, to rendering to produce learning media based on information technology and communication. Based on the above conclusions, during the pandemic, it was suggested that the school through the Principal of Junior High Schools develop e-learning-based blended learning media for all teachers in Muhammadiyah XIV Pondok Pesantren Karangasem Lamongan. Because it can help in achieving learning goals in the Covid-19 pandemic era. The transfer of knowledge that has been given from the UPNV JT Team should be followed up to be developed and informed to teachers who have not participated in direct training and mentoring.

\section{Acknowledgment}




\section{All Authors would like to thank UPN “Veteran Jawa Timur" for support this study}

\section{References}

Astuti, D., \& Novita, D. (2019). Blended Learning terhadap kemampuan Komunikasi Matematis. Prosiding SENDIKA, 5(1), $191-198$. Baharuddin., \& Wahyuni, E. N. (2015). Teori belajar dan pembelajaran. Arruz Media.

Collis, B., \& Moonen, J. (2002). Flexible learning in a digital world. Open Learning: The Journal of Open, Distance and e-learning, 17(3), 217-230.

FitzPatrick, T. (2012). Key success factors of e-learning in education: A Professional development model to evaluate and support elearning. us-China Education Review A, 9, 789-795.

Govindasamy, T. (2001). Successful implementation of e-learning: Pedagogical consideration. The Internet and Higher Education, 4(34), 287-299.

Graham, C. R. (2006). Blended learning systems. The handbook of Blended Learning: Global Perspectives, local designs, 3-21.

Graham, C. R. (2013). Emerging practice and research in blended learning. Handbook of distance education, 3, $333-350$.

Green, G., \& Haines, A. (2015). Asset building and community development. Sage Publication.

Molenda, E. M. (2008). Creating. educational technology: A definition with commentary. New York Routledge, 82-130.

Saba, F. (2011). Distance education in the United States: Past, present, future. Educational Technology, 11-18.

Shroff, R., \& Vogel, D. (2010). An investigation on individual students perceptions of interest utilizing a blended learning approach. International Journal on E-learning, 9(2), 279-294.

So, H., \& Bonk, C. (2010). Examining the roles of blended learning approaches in Computer-Supported Collaborative Learning (CSCL) environments: A delphi study. Journal of Educational Technology and Society, 189-200.

Yaman, M., \& Graf, D. (2010). Evaluation of an international blended learning cooperation project in biology teacher education. Journal of Educational Technology-TOJET, 9(2), 87-96.

Yuen, A. (2011). Exploring teaching approach in blended learning. research and practice in technology enhanced learning, 6(1), 3-23.

Zuvic-Butorac, M., Roncevic, N., Nemcanin, D., \& Nebic, Z. (2011). Blended e-learning in higher education: Research on students perspective. Issues in Informing Science and Information Technology, 4(8), 410-428. 